\title{
From Bazaars to Shopping Centers
}

\section{ReIhaneh Khorrami Rouz}

\author{
Department of Architecture, I.A.U of Dubai, Dubai,U.A.E Knowledge Village,Block 4A,I.A.U, U.A.E
}

rayhaneh.khorami@gmail.com

\section{Doi:10.5901/mjss.2014.v5n23p1875}

\section{Abstract}

In every age, one of the main purposes of architects and urban planners is to change and modify architecture in order to improve the social life, and all the different methods of architecture which have been developed by the passing of time cause changes in spaces. Architects have welcomed those changes which have been able to meet people's needs. However, some other changes have not been able to meet people's needs. Of the spaces which have been changed is the Iranian bazaar. It has undergone many changes and alterations. Some of these bazaars have been destructed, some have turned into an inactive historical monument, and others have persisted to exist in spite of changes. By the passing of time, changes in bazaar or in any other spaces evidently seems essential and inevitable but since modern shopping centers seem to be inappropriate substitution for bazaars, this paper has investigated the bazaars and shopping centers and their changes with the aim of evaluating the strengths and weaknesses of these two places so that finding their advantages and disadvantages can lead to better designs in future. The obtained achievements indicate that the lively atmosphere of bazaars does not exist in the shopping centers and such centers are simply considered as a place to satisfy the material needs of people. The absence of ideas and concepts are evident in most shopping centers of Iran. While nowadays shopping is regarded as a form of entertainment for the modern human, paying greater attention to shopping centers and improving them can significantly cause them to upgrade and they can become a place for entertainment and social interactions of modern human.

Keywords: market, shopping, social life, evolution

\section{Introduction}

Nowadays, shopping is one of the most fundamental elements of a modern lifestyle and shopping centers and spaces are considered as one of the main urban public places. These centers should be able to create a suitable environment for social interactions and act as important urban centers. However, in our modern shopping centers, these factors cannot be seen. All the positive qualities of urban spaces such as excitement, coherence, density, etc. must be included in the shopping centers so that they can act as an ideal urban space and a major center for urban interactions. In contrast with the shopping centers (with regard to qualitative aspects of urban spaces), there is the Persian bazaar which serves as the backbone of the city and has been an important urban center with multiple functions.

However, the ideal urban spaces of that time have become the contemporary shopping centers over time. Comparative study of markets and shopping centers marks the differences between these two locations so as to use the markets as a pattern to design the shopping centers and improve these spaces for social interaction and they can serve as an ideal urban space. Examining the evolution of markets also helps in better understanding of the two spaces and their trends in Iran.

\section{Methodology of Research}

The present study is aimed at comprising bazaar and shopping centers as public urban spaces and at evaluating the positive and negative effects of them.

In this method, information from the past is gathered and analyzed. Information is usually qualitative. Noticeable is that the goal of the study is not to review a summary of the past information, but to demonstrate new knowledge. (Haj Bagheri, 2011, p. 80)

\section{Bazaar General Introduction}

The Iranian bazaar with different economic, social and religious functions is one of the symbols of civic structures with a 
pivotal role. Home of many public activities, bazaar has been the heartbeat of cities. Different wholesale and retail businesses, street marketing, money exchange, import and export, religious, social, political, educational and cultural activities, all have been carried out in bazaar. (Mir Salim, 1996, p. 389)

Experts have different definitions for bazaar; what follows is some of them:

Krotis Bach: "Bazaar in Islamic and eastern countries is the place of business, solving political challenges and forming religious movements. As it extends its cover above the city, main events in the city happen in bazaar. In addition, citizens share their knowledge and find news in Bazaar."

Mohammad Mansour Falamaki argued: "Bazaar is actually a group of stores under a roofed structure. Virtually it bears wide range of concepts from credit to power and merit to success."

George Klark wrote "Bazaar is the highest and most functional business center ever built by the hand of human. Nowadays, developed countries establish shopping centers and business centers. In general term, bazaar is the center for producing and distributing activities; it is a decent system for social and economic activities and plays a significant role in urban structure." (Shafaghi, 2006, p. 39)

In his definition of bazaar, Kamran Adl writes: "Bazaar is a group of public facilities such as bath, mosque, school, tekye ${ }^{1}$, saghkhane ${ }^{2}$, and zorkhaneh ${ }^{3}$ to form a complete and uniform texture to host different social, religious and political activities of people."

Bazaars were generally built at the city gates and were extended to the central parts. Thus, they acted as one of the main access ways in the old cities.

Bazaar supplies the demands of all social classes through providing a wide range of products with a variety of qualities. (Rajabi, 2007, p. 18)

Although bazaar is near the residential areas, there are no facilities in markets to stay overnight. Therefore, bazaar is normally empty during nights and qaysarieh ${ }^{4}$ may take tighter security measures by locking the entrance gates. In fact, one of the reasons that bazaars are secure is that they are free from residents.

Bazaars in different cities have different forms, the majority of them are extended in length, some have been developed organically and some others have been developed based on careful planning.

In fact, bazaar is an important civic spatial and skeletal structure for carrying out business. However, social, leisure, and political activities are common in bazaar.

Bazaar in Islamic cities is also like a home to mosque and civic and governmental buildings. Surrounded by residential neighborhoods, economy and government develop alongside with each other.

\subsection{Philology}

The ancient term "bazaar" is expressed in Pahlavi language as "wacar" and in Achaemenid Farsi as "abacari", in median Farsi is reproduced as "vazar", which is a combination of "vazarg" and "bazargan" and "vazarbar" who is the chief of bazaar or chairman of merchants.

The Farsi term "bazaar" was exported by merchants to other languages, so that it was changed to "pazar" in Azari, "asar" in Russian, "bazar" in French, Italian, German, Arabic and Hindu.

In modern Farsi the term means a place for trading, though it also refers to virtual locations such as "Oil Bazaar" and "Exchange Bazaar".

The term is defined in Dehkhoda Dictionary as "two parallel rows of stores in usually roofed structure, with round squares and alleys". (Dehkhoda, 2002, p. 3348)

And in Amid Dictionary we read "a place for trading goods, gathering of sellers and purchasers, roofed alleys with several stores." (Amid, 2009, p. 271)

\subsection{Characteristics of Bazaar}

1. Separating Bazaar and the residential areas: one of the outstanding characteristics of Bazaar is its independence from domicile. Concerning security, bazaar should be empty at night so that no residential space exists inside it.

${ }^{1} A$ small religious theater in the neighborhood

${ }^{2}$ A small mosque in memory of Imam Hossain (AS)

${ }^{3}$ A place for a traditional Iranian sport named "Varzesh Bastani" in Farsi, meaning "ancient sport".

${ }^{4} A$ part of bazaar and a center of more valuable goods with two lines of shops across from each other 
Another reason is the customary limitations for residential places among Iranians so that the living area should not be visible to total strangers' eyes such as the customers' in markets. Independence of business place and home is an element in Iranian thoughts. (Mir Salim, 1996, p. 336)

2. Bazaar is organized based on business field: business in bazaar is run as an expertise and each discipline of expertise is concentrated in specific locations and this is the cause of formation of rasteh in bazaar (cupper works, jewelry, clothing, etc.). (Soltanzadeh, 2008, p. 40)

There are many reasons to settle different businesses in certain areas of bazaar based on the design of bazaar:

- It helps noisy or troublesome businesses like cupper works, tanning to gather in one place and minimize annoyance for the other businesses (weaving, jewelry, etc.). In addition, specific businesses have different requirements and rooms.

Moreover, there is a competition to win the stores in more crowded passages and this makes the business less thriving and those with less interaction with the customers are being pushed into less crowded, well-priced corners.

- Customers find their demands more easily in discipline-oriented bazaars as they may directly refer to sections where they find their requirements.

- Business-based bazaars are much easier to be monitored and observed by authorities and officials.

- It was believed that businesses are more motivated to compete with their rivals when all participants in a specific business are gathered in certain places.

- Business-based markets make bazaars more comprehensive and provide many advantages and benefits for the businessmen. This helps markets to function as business centers. (Shafaghi, 2006, p. 65)

3. Roofed space: of geographical features of Iran is that it is located in a hot part of the globe, hence, there is the blazing and burning sun in most cities. Roofed architecture of bazaar is in compliance with habitual structure of communities. In addition, roofed structure projects businesses and protects customers from harsh winters and cold. (Shafaghi, 2006, p. 77)

4. Gathering of businesses of same line: businesses with related and supplementary products enjoy the vicinity to each other while businesses with different lines are better-off away from each other. For instance, cosmetic, jewelry and clothing products are commonly located close to each other. (Soltanzadeh, 2001, p. 42)

5. Role of economic value of goods: more profitable businesses handling valuable items like jewelry, money exchange, etc. usually pay more attention to security issues. It is common for them to be more cautious about their security, and due to this fact, they are usually located in central regions of bazaar. (Soltanzadeh, 2001, p. 40)

\subsection{Social functions of Bazaar:}

Along with economic roles, bazaars play other roles as well. One of these roles is the social role. Public facilities are among the elements of bazaar such as public bathrooms, tekyes, mosques, religion schools and ordinary schools which are home of many social activities and relationships.

Wirth believes that bazaar is the center of complicated social relations. (Rajabi, 2007, p. 64)

Due to the formation of bazaars along with main passages in the city, bazaars have become the main passages of the city and therefore they act as a place of communication in order to transfer a great deal of information and news. In addition, jarchis ${ }^{5}$ announce news in the bazaars as the most social and public place of the city. (Soltanzadeh, 2008, $p$. 28)

People used to welcome their important guests from other cities in bazaars since they were usually the main entrance of cities and the main rastehs were the key passages in the city. One of the other social functions of Bazaar was to hold religious rituals. (Behzadfar, Naderi, Frozanmehr, 1388, p. 15)

Government and criminal sentences were usually pronounced or performed in bazaars (Rajabi, 2007, pp. 99-65).

Bazaars were the place of expressing unity and solidarity as they were the home of religious and business unions. Therefore, as an urban and a symbol of civilization, Bazaar was the place of settling possible disputes as well.

In case of emergency and social unrest, bazaars played a pivotal role as a place of gathering and settlement of issues.

Madam Carla Serna writes about Bazaar of Tehran in Qajarieh's reign, "Bazaar is a living and crowded center, where people attend their businesses from dawn to sundown. Bazaar is where people play their social role and discuss business issues. Political discussions and comments about government are also usually heard in bazaar. In general term,

${ }^{5} \mathrm{~A}$ jarchi is a newspaper vendor in the past who read the headlines out loud in bazaar 
bazaar is the place of stock market and parliament. News, gossips, accusations, chaos, backbiting and disclosure of secrets, all are rooted in bazaar". (Soltanzadeh, 2001, p. 31)

\subsection{Political Role}

Bazaar and religion have a long history of peaceful cooperation and usually helped each other to fight against impious governments. Bazaar was a dominant player in political movements such as Mashrouteh ${ }^{6}$ Movement and Iran's revolution.

It is noticeable that security and order are requisites of business growth supposed to be provided by the government. That is why bazaar has always been cautious about its relation with the government, though with the consideration to this fact, it never stopped supporting the public movements.

Religion is an undeniable factor in Iran's society so that every bazaar includes one or more mosques as the sign of prominent role of religion in bazaars.

Michael Bonain believes that mosques and other religious centers played an important role in formation of bazaars so that usually the mosque gates and main rastes are in the same direction. Religious rituals were common in bazaars and they were held with the attendance of merchants and clergies. Such rituals helped empower relationships between bazaar and clergies. (Rajabi, 2007, p. 62)

\subsection{Communicational Role}

Position of bazaar along the main communication axes hints the communicational role of market. Wirth denotes that stores were usually built along passages. Certainly this positioning helped business improvement. Main passage in the city connects different parts of the city and therefore plays an economic, social, and cultural role. (Rajabi, 2007, p. 71)

\subsection{Economic role}

Undoubtedly, economic role of bazaar is the dominant role, as it is the reason of formation of bazaar. However, other roles such as social, cultural and religious were never surpassed by the economic role. This explains the vital role of bazaar in the city and its main role which is to supply public demands. It has always saved its top priority.

Iranian bazaars were the pillars of national economy, and even though they have lost their traditional roles, they are still the center of wholesaling and have the authority to determine the prices. Therefore, the main bazaar of each city is still the main element of that city's economy. (Rajabi, 2007, p. 70)

\section{General Introduction of Shopping Centers}

Shopping centers (also, shopping mall or shopping plaza) are the $20^{\text {th }}$-century version of bazaars and the offspring of industrialization and modern architecture. Shopping centers are comprised of groups of stores in a roofed or unroofed space. These centers also provide services such as restaurant, parking, recreation, hair dressing, etc. Variability in these services depends on size, neighborhood area, and many other factors of shopping centers. (Asadi, 2009, p. 17)

Stores on the street do not constitute a shopping center even if they would be considered as a shopping area. An essential factor of shopping centers is a complex of shops in a roofed or unroofed space.

Shopping centers are classified based on their size and effect:

1. Convenience shopping centers: they include a group of small shops such as restaurants, laundries, barber shops, drug stores, grocery stores, etc. in a small complex usually about $1800-2800 \mathrm{~m}^{2}$.

2. Local shopping centers: they include stores for supplying daily needs such as food, medicine, groceries, personal services, etc. These centers usually take 5 to 10 minutes of driving from home to arrive at them.

3. Community/super-community shopping centers: they include banking, professional, sport services and construction materials such as cements, etc. Regarding the size, the center varies between local and regional centers in an area of 4 to 12 acres.

4. Regional and super-regional shopping centers: they include one or two (three for super-regional centers) chain stores, and the supply a wide range of products such as garments, shoes, home appliances, electronic products, etc. Restaurants and recreational centers are also parts of these centers' supplies. These centers

${ }^{6}$ All the activities in the Qajarieh's dynasty to change the monarchy into democracy 
are usually about 4 to 40 acres.

5. Another type of shopping centers is centers with special purposes which are not located in a specific area. These centers are particularly formed to supply some specified products. (Mehdizadeh Jafari, 2010, p. 13)

\section{Evolution of Bazaar}

Settlement of tribes led to forming a variety of communities in villages and cities, which developed the largest human unit; the society.

Human being has found exchanging a good way to supply his needs. It was initiated by exchanging goods and eventually evolved into economic activities proceeding to the invention of money. Gradually, communities felt the need to a place where business can be carried out and this resulted in emergence of bazaar. (Rajabi, 2007, p. 22)

Archeological excavations have revealed that the first development of permanent settlement and trade-based economy is traced back to 7 thousand years ago in some locations in Iran.

Later, Sumerian, Elamite and Sialk civilizations founded their trade-based economy.

In the City of Ur in Sumer, for example, the archeologists observed some rastehs, on both sides of which, there were some shops deemed as traces of primary markets. (Sultanzadeh, 2001, p. 15) During the Medes' reign, the physical context of market was passing through its early stages and it did not exist as its modern meaning (Habibi, 2005, p. 7). After the Medes, the Achaemenids; who had the dominance over many civilized territories by conquering them, developed a thriving commerce and business and the physical basis of the market began to be shaped. At the time of the Seleucids, the cities mostly were built in Roman-style; they had two perpendicular streets and there was a square at their junction around which the bazaars came into existence. (Pourahmad, 1997, pp. 65-69)

By the time of the Sassanid, the domestic trade grew considerably and the commercial relations between Iran and countries such as China, India, Byzantine, etc. increased and therefore the market was shaped in its modern sense. (Rajabi, 2007, p. 27)

At the beginning of their formation, markets emerged from outside of the gates of Sharestan (a main city) within the city outskirts, and in their subsequent expansions, they found their ways into the city, until establishing themselves in the very heart of the city as its backbone and then continued into the other neighborhoods along their path.

In the following Islamic era and with the presentation of the new Islamic rules, the peace and security of society strengthened the business and trade.

Islamic markets during the Sassanids can be distinguished in two respects: 1. Categorization of the markets on a basis of professions and not necessarily on social classes. 2. Creation of a new market structure (Saraie, 2010, p. 26)

In Islamic era, after the creation of a new element; Grand Mosque, the mosque and the market became the most important structural elements of the city and the market expanded as the backbone of the city and moreover, it was formed in some major villages. The markets had maintained their importance until the Mongols invaded Iran but at the time of the Mongol Empire, many cities and spaces were destroyed resulting in a national economy recession and stagnation. After the Mongol invasion in the Ilkhanite, powerful ministers such as Rashīd al-Dīn Fadhl-allāh Hamadānī brought about an agricultural and business development. In the Ilkhante and the Timurid eras, market remained as one of the leading spatial-functional foundations of the cities.

Iran's economy flourished further in the Safavid dynasty. This period was associated with the emergence of trade unionists and formation of markets, caravanserai and timchehs and qaysarieh all of which were located within one body. Furthermore, additional spaces such as baths, restrooms, schools, tekyes and saqakhanehs were added to the space. In fact, this era can be regarded as the market maturity era of Iran. However, after the Safavids, no important event occurred in connection with the development of markets, and constructing the Vakil Grand Bazaar of Shiraz was considered as an important event. In fact after the Safavid dynasty, Iranian economy was followed by a destructive path. (Sultanzade, 2001, p. 23)

The Qajarieh period was accompanied by many transformations for the market. During this period, the inappropriate management and governmental organization and the influx of foreign capital made the Iranian markets unable to compete with foreign industries and therefore they lost their self-reliance. (Habibi, 1997, p. 112)

Thus, the markets suffered an irreparable damage and those which were the place of supplying the domestic industries and products, became a warehouse for imported goods and lost their earlier importance. (Sultanzadeh 2001, p. 27)

The Pahlavis also followed the trend of the Qajars and the Iranian market continued to remain welcoming to foreign products. On the other hand, using new methods of urban development and formations based on Western modernization led to changes in the structure of markets. Streets and buildings became out of reach and some streets were sliced into 
parts. Likewise, after the Islamic Revolution of Iran in 1979, the destruction continued and the urban development projects still continued to harm the market structure.

All these changes inevitably turned the market into an old, neglected and historic context. However, survival of some markets such as the market of Isfahan, despite all these changes, seems noteworthy.

\section{Comparison between Bazaars and Shopping Centers}

The following table is presented to arrive at a clear understanding of differences between bazaars and shopping centers.

Table 1- Comparison between bazzar and shopping centers

\begin{tabular}{|l|}
\hline Shopping Centers \\
\hline $\begin{array}{l}\text { The spaces are more modular and they have had a more } \\
\text { commercial function. }\end{array}$ \\
\hline The stores have become smaller. \\
\hline $\begin{array}{l}\text { Conglomeration of relative businesses and dispersion of irrelative } \\
\text { businesses have been lost and usually shops with different lines } \\
\text { of business have been located next to each other. }\end{array}$ \\
\hline They lack the security issues and disciplines of bazaars. \\
\hline $\begin{array}{l}\text { There are no priority pre-entrance hallways to access shopping } \\
\text { centers. }\end{array}$ \\
\hline They are located in different areas of the city. \\
\hline They lack the communicative function. \\
\hline They do not play any political role. \\
\hline They can be located in the downtown, in the suburbs, etc. \\
\hline $\begin{array}{l}\text { They have similar architecture in different climatic conditions of } \\
\text { different cities. }\end{array}$ \\
\hline If they are roofed, they apply unnatural methods for lighting and \\
air conditioning. \\
\hline There is no limitation for the number of floors. \\
\hline Their flooring is usually made of stone. \\
\hline There is no priority for choosing the construction site. \\
\hline $\begin{array}{l}\text { There are no physical separations between professions of } \\
\text { different lines. }\end{array}$ \\
\hline
\end{tabular}

\begin{tabular}{|l|}
\hline Bazaars \\
\hline $\begin{array}{l}\text { Bazaars had a variety of spaces from the form and } \\
\text { function viewpoints. }\end{array}$ \\
\hline The stores were more spacious. \\
\hline $\begin{array}{l}\text { Shops of same lines of businesses were located in } \\
\text { certain rastehs. }\end{array}$ \\
\hline $\begin{array}{l}\text { Although crowded, bazaars provided high security for } \\
\text { the pedestrians and shoppers. }\end{array}$ \\
\hline $\begin{array}{l}\text { They owned hierarchically pre-entrance hallways } \\
\text { prioritized on a professional basis to access each } \\
\text { rasteh. }\end{array}$ \\
\hline $\begin{array}{l}\text { The structure of bazaars was a centrally connected } \\
\text { series of shops in a certain area of the city }\end{array}$ \\
\hline $\begin{array}{l}\text { Bazaars possessed the communicative function and } \\
\text { they also worked as the crossover of the city. }\end{array}$ \\
\hline $\begin{array}{l}\text { Bazaars played a significant role in people's political } \\
\text { lives. }\end{array}$ \\
\hline Bazaars were located in the downtown \\
\hline $\begin{array}{l}\text { The architecture of bazaars was completely } \\
\text { compatible with the climatic condition of that region. }\end{array}$ \\
\hline $\begin{array}{l}\text { Depending on the region, if bazaars were roofed, } \\
\text { there would be some holes on the ceiling for lighting } \\
\text { and ventilating the space. }\end{array}$ \\
\hline $\begin{array}{l}\text { They are usually one-story (ground floor) structures } \\
\text { and maximum two-story in some spaces. }\end{array}$ \\
\hline $\begin{array}{l}\text { Bazaars' paving used to be usually built by } \\
\text { condensed soil and sometimes by paving stones. }\end{array}$ \\
\hline $\begin{array}{l}\text { They were adjacent to important city elements such } \\
\text { as mosques, schools and government bodies. }\end{array}$ \\
\hline $\begin{array}{l}\text { Spatial separation based on value, price and } \\
\text { attraction of the goods (rasteh for less important } \\
\text { goods and qaysarieh for the expensive goods). }\end{array}$ \\
\hline
\end{tabular}

\section{Conclusion}

The information given in this paper illustrates that bazaars have gone through ups and downs in different historical periods. Depending on the kings' and ministers' tendency towards the architecture, bazaars have undergone alterations. In Qajar era, with the advent of industrialization and acquiring western culture, bazaars gradually lost their importance and attention towards them was replaced with attention towards modern spaces. In Pahlavi era, this attention was intensified and malls such as Plasco and Aluminum Building appeared. By emerging straight streets in this period, bazaars were divided into many parts or became rundown. But the Iranian bazaars were so powerful that in spite of all these inevitable changes, some of them still have continued to exist and are the heartbeat of the urban economy. Shopping centers which appeared after these periods had different patterns and views but in most of them, the blind imitation from western shopping centers, ignorance of Iranian architecture existed; there were no accounting for social, cultural and recreational viewpoints. These shopping centers are not appropriate substitutes for bazaars and in effect, 
bazaars somehow were in control of destiny to be replaced by them. Historical researches show that bazaars were perfect spaces with different political, social, economic, religious and communicative aspects and their influence on the people's lives was so remarkable that most of demonstrations and revolutions have started from there. There were important urban spaces in bazaar and its neighborhood and also bazaar was a place to spend leisure time. But the shopping centers do not possess the functions of bazaar and they only have some economic aspects of it.

This has turned the shopping centers into unimportant spaces and marginalized their economical roles. These problems have decreased people's tendency to appear in shopping centers for recreation and non-economical purposes; consequently the social communication and the opportunity to appear in the society have decreased greatly. If shopping malls are designed properly, they will be one of the most important urban spaces. But now they are spaces for urgent shopping and have no other roles. Therefore, establishing shopping centers with an innovative and a more comprehensive attitude can play a great role in people's lifestyle.

\section{References}

Abbas Zadegan, M., \& Azari, A., Spatial Analysis of the Role of Bazaar in Iranian Cities, Abadi Journal,Vol. 64, No. 29, 2009, pp. 26-30 Abbasi , Z., Time and Lighting designing in Bazaar of Qom, Abadi Journal, Vol. 64, No. 29, 2009 , pp. 38-50

Abdollah Zadeie Torof, A., The Processes by Which Commercial Spaces Undergo by the Eastern and the Western Countries In Terms of Architectural History, Abadi Journal, Vol. 64, No. 29, 2009, pp. 62-64

Amid, H., Amid Dictionary, Farhang Nama Press, 2009

Asadi, I., Shopping Centers Essay: Study Resources, Municipals, Vol. 2, No. 20, 2000, pp. 17-21

Azhari, Z., Isfahan School in Urbanism, University of Tehran Press, 2002

Beheshti S. M., The System of Trade in Bazaars and Its Relationship with Iranian Architecture and Urbanism, Abadi Journal, Vol. 64, No. 29, 2009, pp. 10-13

Behzad Far, M. \& Naderi, S., M, \& Forozanfar, H. (1388); The Function and Social Role of the Traditional Bazaars of Iranian Towns, Abadi Journal, Vol. 64, No. 29, 2009, pp. 14-19

Dehkhoda, A. A., Dehkhoda Dictionary, Tehran University Press, 2007

Davoudi, M. M., Maintaining the Traditional Structure Bazaars and Adapting Them to New Solutions (case study: Bazaar-e-Jannat in Mashhad), Tehran central branch of Azad University, 2007

Dolat, S., Formation of Shopping Malls in Tehran, Architecture \& Culture Journal, Vol. 9, No. 30, 2008, pp. 53-62

Habibi, M., From Shahr to Shahr, Tehran University Press, 2005, pp. 6-9

Haj Bagheri, M. \& Parvizi, S. \& Salsali, M., The Qualitative Research Methods, Boshra Publication, 2011, pp. 79-82

Borden, I. \& Ruedi Ray, K., The Dissertation: An Architecture Student's Handbook, Sorosh-e-Danesh Press, 2008, pp. 209-228

Javan Forozandeh, A., Commercial Centers, Contemporary Small Cities, Architecture \& Culture Journal, Vol. 9, No. 30, 2008, pp. 44-46

Madani Pour, A., Public and Private Spaces of the City, (F. Norian), ICT Organization of Tehran Municipality, 2010, pp. 192-274

Mehdizadeh Jafari, H. Modern Shopping Centers, Jelve-e-Naghsh Journal, No. 3, 2010, pp. 6-15

Ministry of Housing and Urban Development, Persian Bazaars; An Attempt to Document Traditional Market in Iran, Jihad Daneshgahi Publication, 2009

Mir Salim, S. M., Encyclopedia of Islam, Islamic Encyclopedia Office, Tehran, 1996, pp. 314-405

Pourahmad, A., Geography and Functions of Bazaar of Kerman, Kermanology Center Press, 1997, pp. 65-69

Proshani, I., Bazaar, Ketab-e-Marja Press Co., 2010, pp. 1-57

Rajabi, A., From Typology of Bazaar, Agah Press, 2007, pp. 17-70

Saraie, M. H., Changes of Islamic-Iranian Bazaar (a case study of Yazd Bazaar), Iranian-Islamic city, Vol. 1, No. 2, 2010, pp. 25-37

Soltanzadeh, H., From Saras to Shopping Centers, Architecture \& Culture, Vol. 9, No. 30, 2008, pp. 26-32

Soltanzadeh, H., Iranian Bazaars, Iran Culture Studies, Tehran, 2001, pp. 10-45

Soltanzadeh, H., Tabriz; A Permanent Brick in the Architecture of Iran, Cultural Researches Office Press, 2010

Shafaghi, S., Big Bazaar of Isfahan, Cultural Organization of the Municipality Press, 2006, pp. 36-85

Shafaghi, S., A Structural and Spatial Physical Survey of the Bazaar in Isfahan, Geographical Research Issue, 60, 2001, pp. 23-51

Tabdili Z., Shopping City, Tehran Central Branch of Azad University, 2005, pp. 4-12 